University of Nebraska - Lincoln

DigitalCommons@University of Nebraska - Lincoln

8-1986

\title{
Paleoclimates in Southwestern Tasmania during the Last 13,000 Years
}

Vera Markgraf

Institute of Arctic and Alpine Research, University of Colorado, Boulder, Colorado 80309

J. Platt Bradbury

U.S. Geological Survey, Denver, Colorado 80225

J.R. Busby

Bureau of Flora and Fauna, GPO Box 1383, Canberra, A.C.T. 2601, Australia

Follow this and additional works at: https://digitalcommons.unl.edu/usgsstaffpub

Part of the Earth Sciences Commons

Markgraf, Vera; Bradbury, J. Platt; and Busby, J.R., "Paleoclimates in Southwestern Tasmania during the Last 13,000 Years" (1986). USGS Staff -- Published Research. 252.

https://digitalcommons.unl.edu/usgsstaffpub/252

This Article is brought to you for free and open access by the US Geological Survey at DigitalCommons@University of Nebraska - Lincoln. It has been accepted for inclusion in USGS Staff -- Published Research by an authorized administrator of DigitalCommons@University of Nebraska - Lincoln. 


\title{
Paleoclimates in Southwestern Tasmania during the Last 13,000 Years
}

\author{
VERA MARKGRAF \\ Institute of Arctic and Alpine Research, University of Colorado, Boulder, Colorado 80309 \\ J. PLATT BRADBURY \\ U.S. Geological Survey, Denver, Colorado 80225 \\ J.R. BUSBY \\ Bureau of Flora and Fauna, GPO Box 1383, Canberra, A.C.T. 2601, Australia
}

PALAIOS, 1986, V. 1, p. $368-380$

Plant-sociological and climatic classification of the Australian Nothofagus cunninghamii rain forest provides the basis for a new, semiquantitative approach to interpretations of late-Quaternary paleoclimates from four pollen sequences in southwestern Tasmania. Varying proportions of rain-forest pollen types in the records were related to different modern rain-forest alliances and their specific climatic regimes, such as Eastern Rain Forest, Leatherwood Rain Forest, and sclerophyllous, Subalpine Rain Forest. According to this interpretation, early Holocene climates were characterized by $1,600 \mathrm{~mm}$ annual precipitation and $10^{\circ} \mathrm{C}$ annual temperature, conditions substantially warmer and drier than previously thought. Maximum precipitation levels of $2,500 \mathrm{~mm}$ annually were not reached until 8,000 years B.P. A short-term cooling episode between 6,000 and 5,000 years B.P. led to the establishment of modern rain-forest distribution in western Tasmania, characterized either by a precipitation gradient steeper than before, or by greater climatic variability. To interpret paleoclimates from before 12,000 years B.P., when non-arboreal environments dominated in western Tasmanian pollen records, various modern treeless environments were studied in search for analogs. Contrary to earlier interpretations, late-glacial environments were not alpine tundra with a treeline at modern sea level, but steppe, with marshes or shallow lakes instead of the modern lakes. Climate was characterized by $50 \%$ less precipitation than today, resulting in substantial summer droughts. To explain such drastic precipitation decrease, the westerlies that dominate Tasmanian climate today must have been shifted polewards. This suggestion is supported by climate models that take Milankovitch-type insolation differences into account as well as sea-surface temperatures. Paleolimnological information based on diatom analyses support the general paleoclimatic reassessment.

\section{INTRODUCTION}

Calibration of a fossil record in terms of its paleoclimatic signal is limited, in part, by our lack of knowledge concerning the relationship between modern species assemblages and their climatic determinants. In the case of modern palynological data, climatic calibration generally involves two steps: 1) analysis of the relation between pollen assemblages and vegetation; and 2) analysis of the relation between vegetation and climatic parameters. As a result of these calibrations, particular groups of taxa emerge that in the case of pollen are representative of a specific vegetation, and in the case of plants are representative of a specific climatic regime. Only the taxa of these particular groups are meaningful representatives of the specific calibration, while the remainder of taxa have to be considered noise that obscures the signal (Bryson, 1985). In terms of paleoclimatic reconstruction, the use of specific taxa has been a long-standing habit with palynologists (Faegri and Iversen, 1975), but has been recently re-emphasized by Bryson (1985) who specifically addressed the question of modern analogs. Even under circumstances where analogs do not seem to exist, "partial analogs" may be the answer for interpreting past environments (Bryson, 1985).

In addition to the limited number of taxa that are considered significant, most pollen records have other constraints, such as limits of resolution in time (dating control) and in space (regionality of pollen dispersal). Consequently, primarily only largescale, regional patterns can be defined (Webb and Bryson, 1972; Bryson, 1985).

When attempting to compare the paleoclimates of Argentina and Tasmania (Markgraf, 1984), it became apparent that the species richness in the Tasmanian records (Macphail, 1976, $1979,1983)$ had to be reduced before an underlying, large-scale paleoecologic and paleoclimatic pattern could be distinguished. Two approaches were chosen to gain this end. First, modern pollen samples were analyzed from sedimentary environments

$0883-1351 / 86 / 0001-0368 / \$ 03.00$ 
that could be related to the fossil pollen records and would represent the major, modern environmental and climatic conditions in Tasmania. Second, results from recent plantsociological studies of Tasmanian rain forests (Busby, 1984) were analyzed for representation of taxa in specific vegetation types, and relationships between vegetation types and climatic factors.

The results of these two independent lines of research showed the following: 1) there is a regional group of pollen and plant taxa that differentiates the various vegetation types along a temperature and precipitation gradient, and 2) specific temperature and precipitation regimes are highly correlated with specific groups of modern rain-forest taxa at a level apparently indifferent to local, site-specific edaphic and geomorphologic characteristics, including fire history. These results do not imply that local factors do not influence the local vegetation and consequently the local pollen assemblages. Instead they demonstrate that beyond the local level there is consistency in the relation of modern pollen, plant, and climate data at the regional level, which suggests that large-scale climatic forcing is responsible for truly regional plant and pollen assemblage groups.

This study describes the two approaches used for climatic calibration of modern plant and pollen assemblages and its application to fossil pollen assemblages from four sites in southwestern Tasmania, extending back to about 13,000 years B.P. The proposed paleoclimatic interpretations are then compared with paleolimnologic information based on diatom analyses of two of the four records (Bradbury, 1986).

\section{PALEOENVIRONMENTAL AND PALEOCLIMATIC BACKGROUND}

Even though several pollen records from Tasmania extend beyond the full-glacial (Colhoun et al., 1982; Macphail and Colhoun, 1985), our paper addresses only the last 13,000 years-B.P. interval. All the Tasmanian pollen records analyzed so far show "uniformity in late last-glacial pollen assemblages" (Macphail, 1979, p. 333), dominated by Poaceae (Gramineae, i.e., grasses), Asteraceae (Compositae tubuliflora, i.e., sunflowers), Chenopodiaceae (goosefoot), and CyperaceaeRestionaceae (sedges). Despite this uniformity, these pollen assemblages are interpreted as reflecting "sparse grasslands (possibly chenopod-steppe association) in eastern Tasmania and either grasslands or palynologically unrecorded formations such as sclerophyll heath and sedgelands in western Tasmania" (Macphail, 1975, p. 298). This interpretation is based on the assumption that the pollen assemblages do not contain predominantly local and extralocal pollen, but pollen from "well represented taxa in the downslope and regional vegetation" (Macphail and Colhoun, 1985, p. 44). Consequently, "lowland vegetation was alpine to subalpine in character," with "a climatic timberline (of Eucalyptus) at about present sea level on the west coast" (Macphail, 1979, p. 333). Even though modern temperate-alpine and subalpine vegetation is characterized by uniformly moist and cool conditions without significant seasonal moisture stress, the pollen data supposedly reflect "dry conditions in lowland northwestern, northeastern, and eastern Tasmania" (Colhoun, 1983) or an "effectively drier climate" (than at present) (Macphail and Colhoun, 1985).

Beginning about 11,500 years B.P., increasing amounts of
Eucalyptus pollen, followed by "transient establishment of alpine conifer associations" and, finally, the appearance of rainforest taxa were taken to signal an upslope movement of the Eucalyptus timberline and other elevationally controlled vegetation belts (Macphail, 1979, p. 333). This shift is interpreted as reflecting rising temperatures and precipitation values ("climatic optimum," Colhoun, 1983). 6,000 years before present, sclerophyllous and shade-intolerant trees expanded, indicating declining temperatures and precipitation under drought- and frost-prone climates (Colhoun, 1983). At this relatively large scale, environmental changes in Tasmania are considered synchronous and even parallel to changes in New Zealand and Chile, which were interpreted as reflecting "the same primary cause" (Macphail, 1979, p. 306).

Given the high quality of the Tasmanian records and several new developments in our understanding of species distribution in relation to climate (e.g. Busby, 1984, 1986), a reassessment seems appropriate. Even though still quite crude, our new approach could represent the first step in Tasmania towards the quantitative calibration of pollen data in terms of climate so successfully applied elsewhere (Webb, 1985; Bartlein et al., 1984).

\section{METHODS}

\section{Modern Vegetation}

The present vegetation of Tasmania, recently mapped by Kirkpatrick and Dickinson (1984), can be summarized in terms of four zones. The western and southwestern area $(\sim 35 \%$ of the State) is largely occupied by rain forest, wet scrub, buttongrass moor, and Eucalyptus simmondsii wet forest. The Central Plateau $(\sim 15 \%)$ supports several alpine and subalpine complexes of heath and herbland, high-altitude tussock grassland, montane grassy forest, and Eucalyptus delegatensis forest. The north coast, midlands, east, and southeast $(\sim 40 \%)$ contain drier forests, woodlands, and heath; and the north-east highlands $(\sim 10 \%)$ contain additional rain forest along with Eucalyptus delegatensis and $E$. obliqua forest. Our study used the floristic classification of Busby (1984) for rain-forest and closely allied vegetation containing Nothofagus cunninghamii (plant taxa mentioned are listed with information on authority, family, and growth form in the Appendix). N. cunninghamii occurs in both Tasmania and, to the north, Victoria (southeast Australia) and is a species indicative of cool, wet environments. It occurs from sea level to around $1,200 \mathrm{~m}$ in subalpine vegetation in western Tasmania (Busby, 1984). Comparable analyses for other vegetation types are not yet available.

\section{Climate}

The present climate of western Tasmania is cool and wet; under the influence of prevailing westerly winds, with mean annual temperatures of around $11^{\circ} \mathrm{C}$ near sea level to less than $6^{\circ} \mathrm{C}$ at $1,000 \mathrm{~m}$. The topography, although seldom exceeding $1,200 \mathrm{~m}$ above sea level, is mountainous and induces a steep precipitation gradient from west to east. Mean annual precipitation ranges from over $3,500 \mathrm{~mm}$ on mountains near the coast to less than $500 \mathrm{~mm}$ in the east. Precipitation is distributed throughout the year but with a winter maximum. Light frosts 


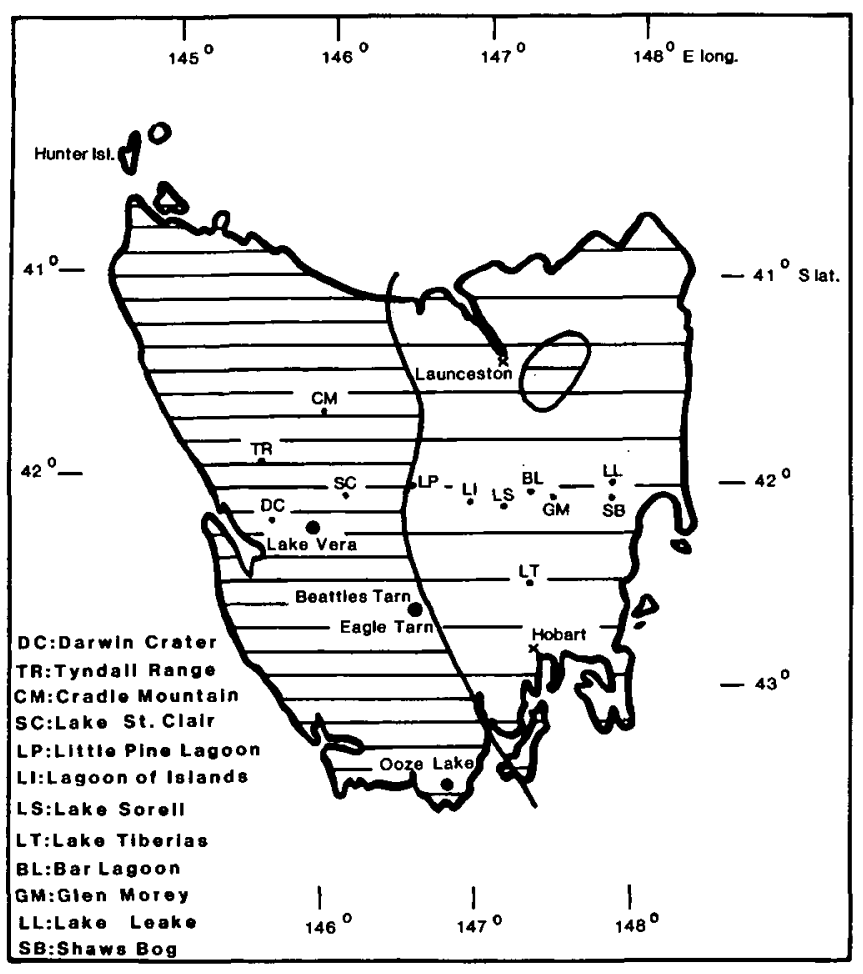

FIGURE 1-Map of Tasmania showing sites of modern pollen samples $(\bullet)$ and pollen records $(\bullet)$. Closely spaced lines indicate regions of moisture surplus; more widely spaced lines indicate moisture deficit, following radiation-index-of-dryness study by Nunez (1978).

can occur throughout the year and snow can fall at any time, particularly at higher elevations.

Tasmania's position of $40^{\circ}$ to $44^{\circ} \mathrm{S}$ latitude is near the northern edge of the westerlies and results in a great variability of pressure patterns, alternating between influences from highpressure systems around latitude $30^{\circ} \mathrm{S}$ and low-pressure systems south of latitude $45^{\circ} \mathrm{S}$.

A climatic parameter that demonstrates the ecological significance of the temperature and precipitation gradient is the radiation index of dryness, calculated and mapped for Tasmania by Nunez (1978). This index distinguishes regions with moisture surplus (the regions where mean annual precipitation is above $1,200 \mathrm{~mm}$ and where rain forests grow) from regions with moisture deficit (where mean annual precipitation is below 1,200 $\mathrm{mm}$ and Eucalyptus woodlands expand). The surplus/deficit boundary in Tasmania broadly coincides with the rain-forest boundary (Fig. 1) and suggests that most vegetation types east of that boundary experience a seasonal (summer) moisture stress. High-elevation regions, however, even with less than $1,200 \mathrm{~mm}$ mean annual precipitation, do not experience such moisture stress, because of cooler temperatures. Thus, subalpine and alpine sites are characterized by moisture surplus.

In the vegetation analysis of Busby (1984), individual sample sites were allocated to vegetation types on the basis of their floristic composition. For the present study, monthly temperature and precipitation estimates were derived for each of those sites, thereby enabling characterization of each vegetation type by the climatic parameters of its constituent sites. Climatic averages for those vegetation types that were considered analogous to those detected in the pollen record were thus used as estimates of past climates.

Estimates of climate for individual vegetation- and pollensample sites were obtained from mathematical surfaces fitted to data obtained from the Australian Bureau of Meteorology, using an algorithm first described by Wahba and Wendelberger (1980) but implemented in an enhanced, approximate form by Hutchinson (1984). These surfaces were obtained as part of an extensive climatic analysis for the Australia BIOCLIM System (Nix, Busby, and Hutchinson, in prep.) and, more generally, as part of the Australian Environmental and Geographic Information System currently being developed by the Division of Water and Land Resources, CSIRO (Commonwealth Scientific and Industrial Research Organization), and other agencies.

The algorithm fitted a function of three independent variables (latitude, longitude, and elevation of meterological stations) to measured climatic values at each station, for each month independently (Hutchinson, 1983). The degree of data smoothing imposed by each fitted surface was chosen to minimize the predictive error of the surface as measured by the generalized cross validation (GCV) (Hutchinson, 1983). The GCV was calculated by excluding each data point, in turn, and evaluating the degree to which that value was estimated by the remaining data. The surface-fitting procedure provided an estimate of the variance of the data, which was compared with a priori estimates to check the goodness of fit of the model, and also provided an estimate of the true error of the fitted surface over the analyzed region.

Monthly mean minimum and maximum temperature estimates were derived from Australia-wide surfaces fitted to measure data from 901 meteorological stations throughout the country. The station values were uniformly weighted, in the absence of reliable information about the length of record for each station. Estimates of the mean true error, averaged over the data points used, were less than $0.5^{\circ} \mathrm{C}$ for every month of the year for both maximum and minimum temperatures. The errors associated with the Tasmanian region of the national surface are not known, but comparisons between measured and estimated values for individual high-elevation stations (where the largest errors would be expected because of the few measurements available) showed differences of no more than $1.5^{\circ} \mathrm{C}$ for individual months, with most differences less than $1^{\circ} \mathrm{C}$.

Precipitation estimates were derived from surfaces fitted to measured data from 504 Tasmanian rainfall stations, including data obtained from the Tasmanian Hydro-electric Commission, for the period between 1901 and 1975 and with a minimum length of record of five years. The station values were weighted by the number of years of record. Estimates of the mean true error at the data points ranged from $6 \mathrm{~mm}$ (9\% of the average monthly mean) in summer to $9 \mathrm{~mm}$ ( $8 \%$ of the mean) in winter.

\section{Modern Pollen Spectra}

Macphail (1976, 1979) established qualitative relationships between local plant cover and pollen assemblages by analyzing atmospheric pollen collected in Tauber traps, and pollen in 
moss polsters and surface sediment samples. The relation between pollen and plant taxa in a given vegetation type depends on the type of sample. For example, pollen frequencies obtained from moss polsters generally show higher correlations with local-plant frequencies than surficial sediment samples from even small basins that show predominance of extralocal and regional plant components (Janssen, 1973; Webb et al., 1981; Prentice, 1985). Because the Tasmanian pollen records reassessed here are from lakes, we concentrated on modern pollen samples from surficial lake sediments. Samples were collected at wading depths in shallow lakes and with a grab sampler in deeper lakes (Lake St. Clair, SC). These surface mud samples represent several years of sediment and pollen input and generally compare well with core-top samples from the same basin.

The choice of lakes for this study of modern pollen was influenced by attempts to locate lake catchments with combinations of plant taxa that could be related to fossil pollen assemblages. We focused especially on modern pollen data from present-day open vegetation types, including open woodlands such as lowland Eucalyptus savannas in the Tasmanian midlands, subalpine tussock grasslands of the central plateau, and high-elevation alpine heath communities (Fig. 1). By analyzing modern pollen spectra from a wide range of treeless vegetation types we hoped to find out how to interpret the treeless pollen assemblages from the late last-glacial period.

The samples were treated using standard extraction techniques for pollen (Faegri and Iverson, 1975) and counted using a Zeiss microscope with 400 - and 1000 -power magnification. The pollen reference collection in the Department of Biogeography and Geomorphology at the Australian National University aided pollen identification.

\section{Fossil Pollen Records}

Four pollen sequences with adequate dating control of at least two radiocarbon dates were selected: Lake Vera (Frenchman's Cap, $42^{\circ} 16^{\prime} 30^{\prime \prime} \mathrm{S}, 145^{\circ} 52^{\prime} 30^{\prime \prime} \mathrm{E}, 550 \mathrm{~m}$; Macphail, 1976, 1979); Ooze Lake (Southern Ranges, 4330'S, $146^{\circ} 43^{\prime} \mathrm{E}, 880 \mathrm{~m}$; Macphail and Colhoun, 1985); Beatties Tarn (Mt. Field, $42^{\circ} 40^{\prime} 30^{\prime \prime} \mathrm{S}, 146^{\circ} 38^{\prime} 10^{\prime \prime} \mathrm{E}, 990 \mathrm{~m}$; Macphail, 1976 , 1979); Eagle Tarn (Mt. Field, $42^{\circ} 40^{\prime} 50^{\prime \prime} \mathrm{S}, 146^{\circ} 35^{\prime} 17^{\prime \prime} \mathrm{E}, 1,033$ m; Macphail, 1976, 1979).

Lake Vera, the westernmost site, has a mean annual precipitation of $2,830 \mathrm{~mm}$ and a mean annual temperature of $8.7^{\circ} \mathrm{C}$. The local natural vegetation is Nothofagus cunninghamii rain forest near the lower limits of subalpine forest. The sites in the Mt. Field area, Beatties Tarn and Eagle Tarn, are located in the subalpine vegetation zone in mixed rain-forest/snowgum woodland (Nothofagus cunninghamii, Eucalyptus coccifera, $E$. subcrenulata, ) under $1,500 \mathrm{~mm}$ mean annual precipitation and a $5^{\circ}$ to $6^{\circ} \mathrm{C}$ mean annual temperature. Ooze Lake, the southernmost site, in the upper subalpine/ alpine tension zone, is surrounded by stunted Nothofagus cunninghamii trees, and is characterized by $1,850 \mathrm{~mm}$ mean annual precipitation and a $6.2^{\circ} \mathrm{C}$ mean annual temperature (Macphail and Colhoun, 1985).

Percent values of the principal pollen taxa of these four records (selected on the basis of their importance in the modern plant-sociological study, in the modern pollen study, and in their numerical importance in the fossil spectra) were plotted on a chronological scale by interpolating between the radiocarbon dates. The taxa comprise trees and large shrubs such as Nothofagus cunninghamii, Phyllocladus aspleniifolius, the Eucryphia-Anodopetalum type ${ }^{1}$, Lagarostrobos (= Dacrydium) franklinii, and Eucalyptus; herbaceous taxa include Poacea (Gramineae), Asteraceae (Compositae tubuliflorae), Chenopodiaceae, Plantago, and Cyperaceae-Restionaceae; subalpine, sclerophyllous shrubs and herbs include Milligania, Orites, Richea, Bellendena montana, and Tasmannia (= Drimys) lanceolata; and subalpine dwarf conifers include Microstrobos, Microcachrys, Podocarpus, and the Athrotaxis-Diselma type. The percent values are the originally published values, which were based on a pollen sum that exluded dwarf conifers and sclerophyll shrub taxa, Cyperaceae, Restionaceae and, in Lake Vera, Lagarostrobos (see Macphail, 1979).

\section{RESULTS}

\section{Modern Vegetation}

Busby (1984) distinguished two major orders of temperate rain forest in Tasmania, each with a number of subordinate units (alliances, associations, and subassociations) (Fig. 2 and Table 1). The Tasmannia-Astelia Order occurs as low, openshrub vegetation in the subalpine zone of western and southern Tasmania, while the Atherosperma-Blechnum Order ranges from subalpine vegetation in the northeast, through dense montane and lowland rain forest, to rain forest mixed with more open Eucalyptus forest in the southwest. Subgroups of the latter are the Anodopetalum-Anopterus Alliance of western and southern Tasmania and the Dicksonia-Polystichum Alliance of central, northwestern, and northeastern Tasmania. The most prominent component of the latter Alliance in Tasmania, the Dicksonia-Polystichum Association, has three Subassociations, including the Pomaderris apetala Subassociation, which is now confined to northern and southeastern Tasmania. All these alliances are altitudinally, but not geographically, separate throughout southwestern Tasmania (Fig. 2). Relative occurrences of some of the prominent rain-forest species in these vegetation types and selected climatic characteristics are given in Table 1.

\section{Modern Pollen Data}

The pollen types analyzed in the modern surface sediment samples are plotted in Figure 3 as a percentage of the total pollen sum. The sites are arranged along a west-east transect through Tasmania, corresponding to the decreasing-precipitation gradient. Precipitation and mean annual temperature data, derived from the climatic estimates discussed in METHODS, are plotted for each sampling site. Pollen data from Cradle Mountain (CM), Mawson Plateau (MP), and Beatties Tarn (BT) are from Macphail (1975, 1976). Pollen percentages of these samples were recalculated to include subalpine conifers, sclerophyllous shrubs, Cyperaceae, and Restionaceae.

1"type" is used to designate pollen grains that are morphologically similar 


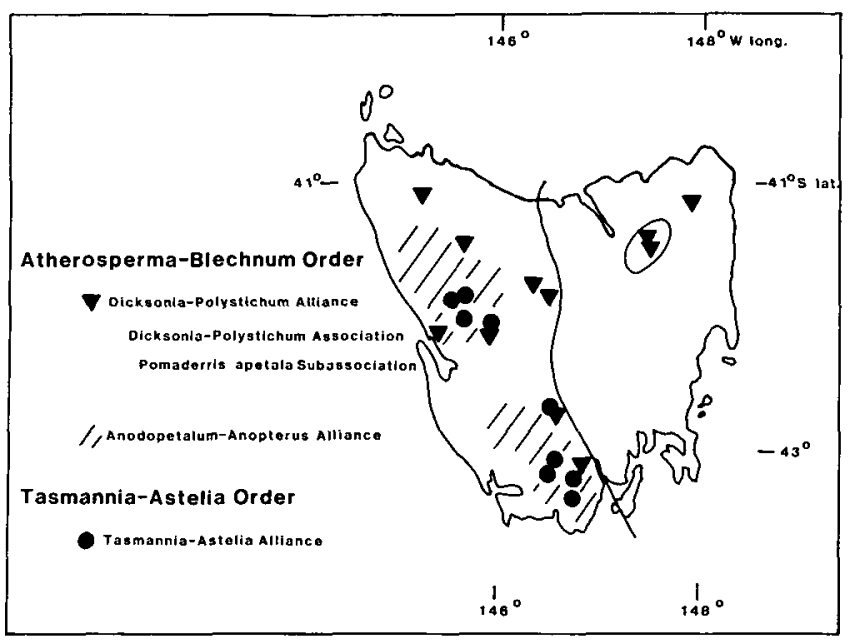

FIGURE 2-Geographic distribution of Nothofagus cunninghamii rainforest alliances in Tasmania. For relative occurrences of plant taxa in these alliances, and selected climatic characteristics, see Table 1.

Figure 3 shows that, despite site-specific differences in plant-taxa composition and degrees of disturbance (Kirkpatrick and Dickinson, 1984), pollen frequencies reflect a large-scale, consistent pattern, representing the major vegetation types along both the elevational and the west-to-east, decreasing-precipitation gradients. The rain-forest sites of western Tasmania, with mean annual precipitation above 1,700 mm (Darwin Crater, DC; Tyndall Range, TR; Cradle Mountain, CM; Lake St. Clair, SC), are comparable in their pollen content, despite the elevational range. The rain-forest components, Nothofagus cunninghamii, Phyllocladus aspleniifolius, Dicksonia antarctica, and Epacridaceae, along with Restionaceae, dominate the spectra with over $60 \%$ of the total pollen sum. Eucalyptus is represented by 20 to $30 \%$, while subalpine conifers and herbaceous taxa amount to only 10 to $20 \%$. It is significant that the high-elevation sample from $300 \mathrm{~m}$ above timberline on Cradle Mountain (Macphail, 1975), is so closely related to the other sites, which are surrounded by rain forest. According to Macphail (1975) the sample came from a shallow hollow at the summit of a "tor" devoid of local vegetation. Thus, only long-distance pollen from forest taxa with high pollen production and regional dispersal, located well below the site, is represented. Pollen types from the alpine heath/grassland are absent, even though their source is closer to the site than is the forest. This finding agrees well with data from other modern pollen dispersal studies from mountain areas, wherein the more exposed sites above treeline contain predominantly arboreal long-distance pollen (Maher, 1963; Markgraf, 1980).

In contrast, the subalpine-heath, mixed rain-forest-Eucalyptus sites, with mean annual precipitation between 1,200 and 1,500 mm (Mount Field: Mawson Plateau, MP; Tarn Shelf, TS; Lake Dobson, LD; and Beatties Tarn, BT) have distinct and well-defined pollen spectra. They are characterized by percentages for subalpine conifers of up to $30 \%$, and by Asteraceae (Compositae tubuliflorae) and Epacridaceae each up to $20 \%$, while rain-forest components total less than $40 \%$ and herbaceous taxa are below $10 \%$. Pollen content from Beatties Tarn differs somewhat from the other subalpine sites by its high proportion of Eucalyptus pollen and lower values of pollen from subalpine conifers and Asteraceae. Located at 990 m elevation, this site is near the lower limit of the subalpine zone, and thus the pollen content probably reflects the close proximity of upper-montane, Eucalyptus delegatensis forest.

A distinct pollen group represents sites in central and eastern Tasmania east of the rain-forest zone. The samples come mostly from Eucalyptus delegatensis forest environments (Little Pine Lagoon, LP; Lake Sorell, LS; Lagoon of Islands, LI; Lake Leake, LL; Shaws Bog, SB; Lake Tiberias, LT; Glen Morey, GM; and Bar Lagoon, BL) with mean annual precipitation below $1,200 \mathrm{~mm}$. In these samples Eucalyptus pollen is the principal arboreal component, accompanied by up to $20 \%$ Poaceae (Gramineae), 5 to $10 \%$ herbaceous taxa, and up to $20 \%$ Cyperaceae pollen. Casuarina pollen is always poorly represented, and Restionaceae pollen is absent. Rain-forest pollen occurs in traces, usually less than $5 \%$. The variable, open nature of the Eucalyptus forest is clearly reflected in these samples by the varying percentages of Poaceae and Eucalyptus. Samples from open woodlands (Shaws Bog, SB; Little Pine Lagoon, LP; Lake Tiberias, LT; Glen Morey, GM; and Bar Lagoon, BL) have over $40 \%$ of Poaceae pollen and less that $20 \%$ Eucalyptus, whereas sites from closed forests (Lagoon of Islands, LI; Lake Sorrell, LS; and Lake Leake, LL) show an inverse ratio of these taxa.

In conclusion, the modern pollen samples indicate that the major vegetation types, as defined by Jackson $(1965,1981)$ and Kirkpatrick and Dickinson (1984), have well-defined pollen spectra. The uniformity of pollen spectra in the Tasmanian rain forest indicates the predominance of extralocal and regional pollen types. This result is significant because it implies that changes in fossil tree-pollen proportions represent regional changes in forest composition that are substantially independent of changes in the local tree composition. In contrast, pollen spectra from non-arboreal or woodland vegetation types represent a predominance of local and extralocal plant taxa, resulting in clearly defined pollen assemblages from the different local vegetation types. Even in Tasmania, with its "abundance of under-represented taxa, i.e. the overwhelming majority of Tasmanian plants" (Macphail and Colhoun, 1985), there is no "palynologically unrecorded" vegetation (Macphail, 1975, p. 298). Thus sites (like Cradle Mountain) that lack local or extralocal vegetation are not characterized by non-arboreal pollen types, but by regionally dispersed types, primarily tree pollen.

Given the regionality of rain-forest pollen spectra, the interpretation of fossil pollen spectra in terms of specific rain-forest plant associations may seem futile. However, because the modern plant-sociological study does document differences in proportions of specific rain-forest taxa that are related to specific climatic parameters, the lack of differentiation in the modern pollen rain must be a function of the small sample size. But because of constraints on the type of sample used (only lake or bog surface samples can be used to provide data on modern pollen that is analogous to the fossil core data), a more 
TABLE 1-Frequency (in percent) of prominent plant taxa in principal Nothofagus cunninghamii rain-forest groups (after Busby, 1984), and selected climatic averages (mean, \pm standard error).

TAXON

Nothofagus cunninghamii
Phyllocladus asplenifolius
Dicksonia antarctica
Epacridaceae
Eucalyptus spp.
Pomaderris apetala
Atherosperma moschatum
Eucryphia spp.
Lagarostrobos franklinii

\section{CLIMATIC CHARACTERISTICS}

\begin{tabular}{lccccc}
\hline Mean annual temperature & 10.0 & 9.6 & 9.3 & 6.2 & $\left({ }^{\circ} \mathrm{C}\right)$ \\
Mean summer temperature & \pm 0.18 & \pm 0.47 & \pm 0.16 & \pm 0.11 & \\
(Jan., Feb., March) & 14.4 & 13.8 & 13.3 & 10.5 & $\left({ }^{\circ} \mathrm{C}\right)$ \\
Mean annual precipitation & \pm 0.20 & \pm 0.43 & \pm 0.14 & \pm 0.09 & \\
& 1,577 & 1,333 & 2,527 & 2,093 & $(\mathrm{~mm})$ \\
Mean summer precipitation & \pm 56 & \pm 49 & \pm 82 & \pm 85 & \\
(Jan., Feb., March) & 253 & 203 & 439 & 364 & $(\mathrm{~mm})$
\end{tabular}

precise definition of analogs among the modern rain-forest assemblages may not be possible for Tasmania. Thus, because a full analog analysis such as that described for North America (Overpeck et al., 1985; Bartlein et al., 1986) is not justified for Tasmania, we used those taxa that "discriminate" most highly between the modern plant associations (Table 1). This approach of "partial analogs" allowed us to correlate the occurrences of specific pollen types in the four fossil records with modern plant frequencies in the rain forest and their specific climatic patterns.

\section{Fossil Pollen Records}

Data from the sociological study of plants in the modern Nothofagus rain forest facilitated evaluation of the modern and fossil pollen assemblages by identifying taxa and climatic pa-

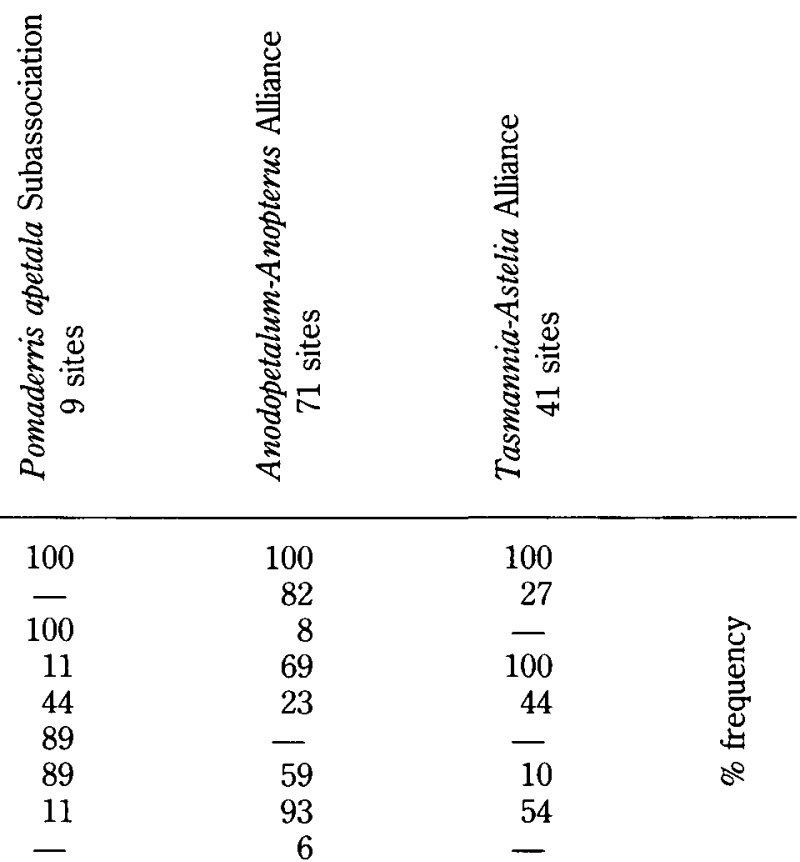

rameters that a) discriminate between the different modern vegetation types, and b) have high present ecological significance based on the taxa's frequencies in specific floristic groups (Table 1). The selection thus was independent of the taxa's abundance in the fossil record, and included abundant types as well as some types that only occurred in low frequencies. These taxa include the arboreal types (Fig. 4a): Nothofagus cunninghamii, Phyllocladus, the Pomaderris apetala type, Dicksonia, Atherosperma, the Eucryphia-Anodopetalum type, Lagarostrobos, Eucalyptus; and the nonarboreal taxa (Fig. 4b): herbs, Poaceae (Gramineae), Asteraceae (Compositae tubuliflorae), Chenopodiaceae and Restionaceae/Cyperaceae, subalpine shrubs and herbs (Milligania, Orites, Bellendena, Richea, Tasmannia), subalpine dwarf conifers (Microstrobos, Microcachrys, Podocarpus, the Arthrotaxis-Diselma type), and Restionaceae/Cyperaceae. 


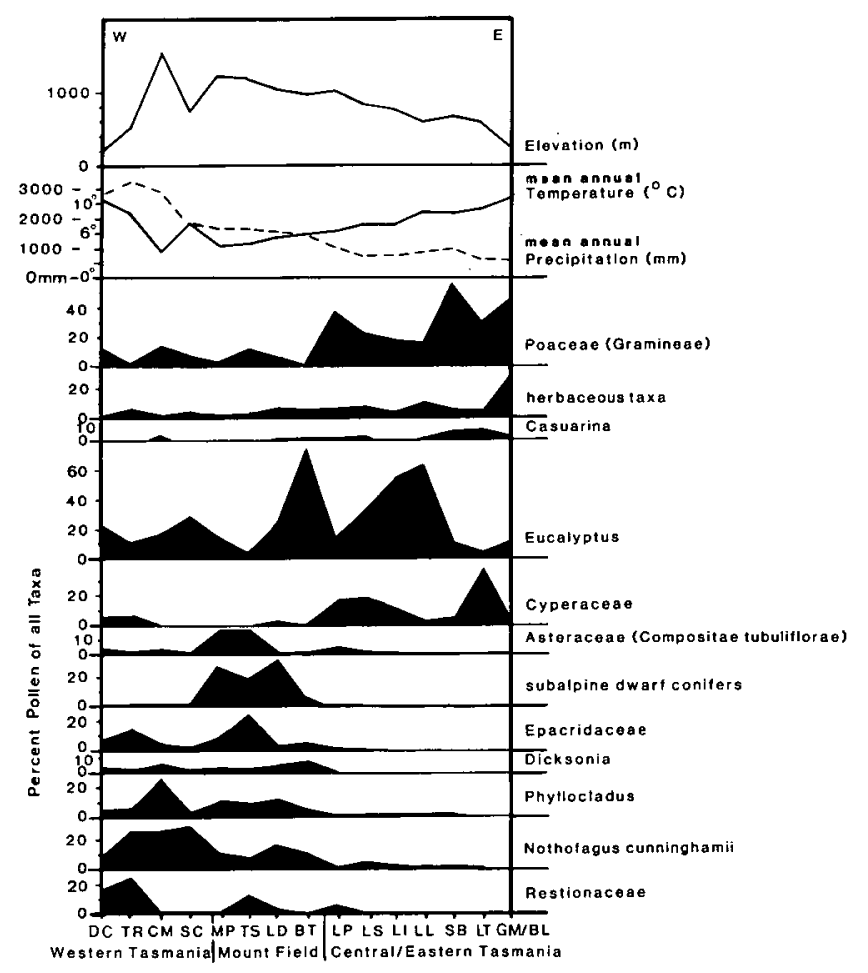

FIGURE 3-Modern pollen spectra from sites in Tasmania. For site names see Figure 1 and text.

The pollen types from the four chosen pollen records are plotted along a time axis that is constructed by interpolation between radiocarbon dates. Eagle Tarn has 14 dates ( 3 original dates [Macphail, 1979] and 11 additional dates on a new core that was correlated to the original core [D. Green, pers. comm. ]); Ooze Lake has 5 dates (Macphail and Colhoun, 1985); and Lake Vera and Beatties Tarn have 3 and 2 dates, respectively (Macphail, 1979). Dating control in all four cases is best between 12,000 and 8,000 B.P., although breaks in the pollen record at the sediment transition from clays to organic muds prior to 11,500 B.P. could imply hiatuses in the Lake Vera and Eagle Tarn records (Macphail, 1979). Despite this uncertainty, large-scale synchroneity of environmental changes occurs in all records, as stressed by Macphail $(1975,1979)$.

In the approximately 13,000 year-long period represented by the four records, six major pollen zones can be distinguished (see Figs. 4a and $4 \mathrm{~b}$ and Table 2). Zone 1, prior to 12,000 years B.P. (or 11,500 years B.P.) is dominated by non-arboreal pollen types. Zone 2 , from 12,000 to 10,000 years B.P., reflects a period of short-term environmental changes. The earlier phase between 12,000 and 11,000 years B.P. is characterized by subalpine conifer and non-arboreal pollen types. By 11,000 years B.P., the rain-forest pollen group gains dominance, especially Phyllocladus. During Zone 3, which lasted from 10,000-8,000 years B.P., Nothofagus cunninghamii and the Pomaderris apetala type reach their highest percentages. The Pomaderris apetala type and the Eucryphia-Anodopetalum type show a definite inverse relation in their percentages.
The following interval, Zone 4 , between 8,000 and 6,000 years B.P., is characterized by relatively high percentages of Phyllocladus and the Eucryphia-Anodopetalum type.

During the interval between 6,000 and 5,000 years B.P. (Zone 5) the pollen assemblage changes markedly, compared with the prior, more subtle changes. Dwarf conifers and subalpine shrubs and herbs reappear after an absence of about 5,000 years. Following this brief interval, essentially modern environmental conditions became established by 5,000 years B.P. (Zone 6).

\section{PALEOCLIMATIC INTERPRETATION OF PALEOENVIRONMENTAL DATA}

Busby's (1984) plant-sociological study of a modern rain forest cannot be used to calibrate the paleoclimatic signal of the late Pleistocene because of the low proportions of rainforest taxa in the period prior to 12,000 years B.P. To calibrate these non-arboreal pollen assemblages in terms of vegetation and climate, modern pollen assemblages from Tasmania were analyzed. Even though complete analogs may not exist (Macphail and Jackson, 1978; Macphail and Colhoun, 1985), partial analogs based on the results of the local and extralocal nature of non-arboreal pollen dispersal may provide relevant ecological information (Table 2). Dominance of Poaceae (Gramineae), Asteraceae (Compositae tubuliflorae), and Cyperaceae/Restionaceae pollen in some fossil assemblages, coupled with the absence of pollen from alpine taxa (such as Astelia and Plantago) in these assemblages, resembles the modern assemblages for the Tasmanian Central Plateau and Midlands combined. Based on modern climatic data from this central Tasmanian region, late Pleistocene precipitation in southwestern Tasmania was at least $50 \%$ less than today and did not exceed $1,000 \mathrm{~mm}$. More significant, however, is the seasonal moisture stress that characterizes this environment (Nunez, 1978), and that could explain the absence of arboreal taxa. The previous interpretation that these non-arboreal assemblages represented "wide spread tundra and steppe during the late Pleistocene" (Macphail and Colhoun, 1985) is in conflict with the climatic data. Tundra and steppe are mutually exclusive; they represent vegetation developing under quite different climatic regimes. Tundra (used synonymously with alpine vegetation) does not experience moisture stress and the absence of trees is due to other factors. Steppe, on the other hand, experiences seasonal drought. Macphail and Colhoun's (1985) ambivalent interpretation derives from the hypothesis that the tundra was the palynologically unrecorded local vegetation and that as a consequence the pollen assemblages originated from the distant, downslope and lowland steppe vegetation. As shown by our modern pollen transect, Poaceae (Gramineae) and Asteraceae (Compositae tubuliflorae) represent local and extralocal vegetation only and could not dominate a pollen assemblage if local vegetation were tundra, heath, or sedgeland, environments that have other pollen assemblages. A fossil pollen assemblage that probably represents a tundra environment is the full-glacial assemblage dominated by arboreal pollen, lowGramineae and Cyperaceae/Restionaceae pollen, and the presence of Astelia and Plantago pollen (Ooze Lake; Macphail and Colhoun, 1985).

Given the similarity of late Pleistocene pollen assemblages 


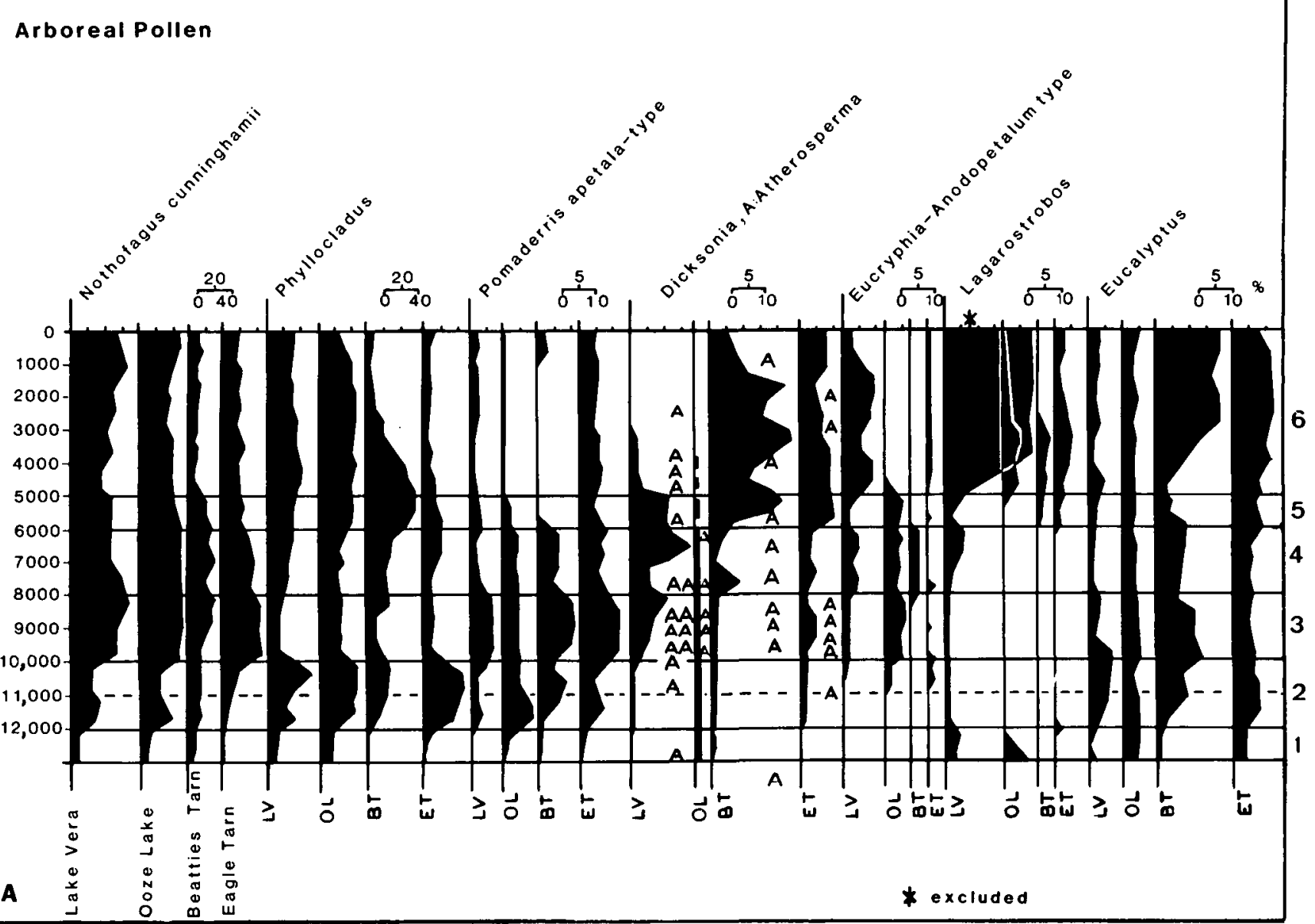

FIGURE 4A_Selected tree-pollen types (in percent) from fossil records from Lake Vera, Ooze Lake, Eagle Tarn, and Beatties Tarn, plotted along a chronological scale by interpolating between radiocarbon dates. Percent data is based on total pollen sum with exception for Lagarostrobos in Lake Vera, which was calculated out-of-the-sum (Macphail, 1976).

throughout southwestern Tasmania, we propose that a steppe environment with marshes (instead of lakes) characterized the final stages of ice-age conditions in Tasmania. The implicit low precipitation and periods of seasonal moisture stress suggest that the influence of the westerlies must have been reduced. Global climatic modeling based on orbitally forced insolation differences (Kutzbach and Guetter, 1984) predicts an $8^{\circ}$ poleward shift of the westerlies during full-glacial and late-glacial times as a consequence of the steepening of the general temperature gradient and the much-cooler oceans west of Australia. This shift and the resulting southwesterly winds over Tasmania should result in reduced precipitation.

Support for late Pleistocene aridity comes also from diatom analyses of Lake Vera and Eagle Tarn (Bradbury, 1986). By 12,000 years B.P. both were shallow lakes that supported benthic and epiphytic diatoms. The fossil assemblages contain two distinct communities, an alkaline, slightly saline association and an association that lived in very dilute, circumneutral to slightly acidic water. The presence of both assemblages in the same levels apparently reflects seasonal hydrochemical changes, probably under climatic control. A summer season of moisture stress, alternating with a winter season of high precipitation, would account for the co-occurrence of these distinct assemblages.

Support for Pleistocene aridity comes also from eastern Tasmania. Dunes were supposed to have been active during this time (Bowler, 1982) and the high degree of plant endemism is explained by aridity (Noble, 1986). Late Pleistocene paleoenvironmental data from New Zealand suggest that aridity was even more widespread, affecting both islands (McGlone and Topping, 1977; McGlone and Bathgate, 1983).

From 12,000 years B.P. onwards the modern rain-forest taxa began to replace the non-arboreal taxa. In all four records, proportional abundances of rain-forest taxa vary similarly through time (Table 2). For most time periods these pollentype abundances can be related to the floristic groups distinguished in the study of the modern rain forest and to their climatic characteristics (Busby, 1984).

The earliest interval with rain-forest components, dated between 12,000 and 10,000 years B.P. (Zone 2 ), is character- 


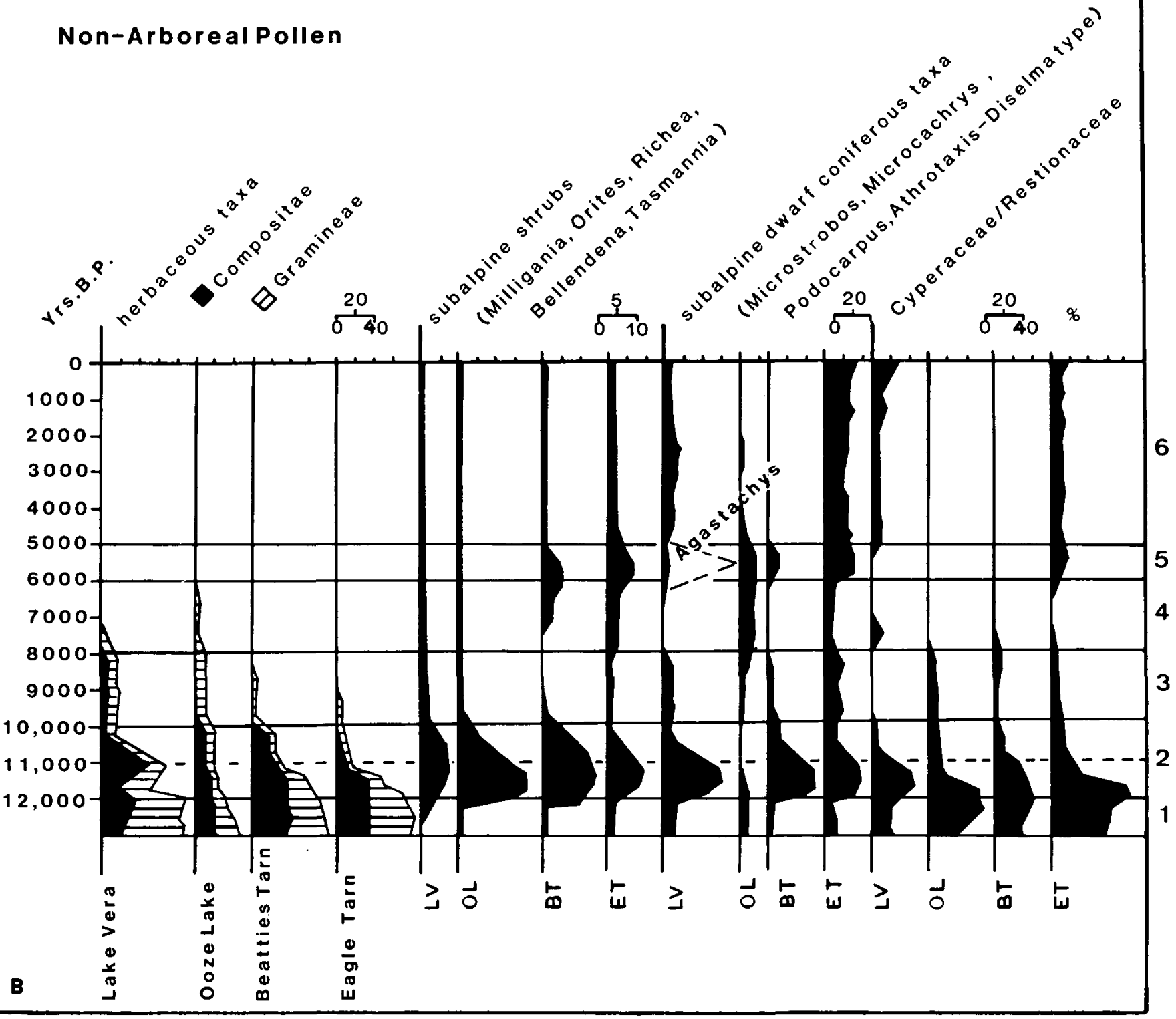

FIGURE 4B-Selected non-arboreal pollen types (herbs and shrubs) in fossil records from Lake Vera, Ooze Lake, Eagle Tarn, and Beatties Tarn. Percent data is based on total pollen sum (Macphail, 1976; Macphail and Colhoun, 1985).

ized by high amounts of subalpine shrubs, dwarf conifers, herbs, and Asteraceae (Compositae tubuliflorae), in addition to Nothofagus cunninghamii, Phyllocladus, Eucalyptus, and Astelia. With the exception of the presence of the Pomaderris apetala type this pollen group resembles the TasmanniaAstelia Alliance. The corresponding climate would call for relatively low temperatures $\left(6^{\circ} \mathrm{C}\right.$ annually). Precipitation, however, could not yet have reached the levels found in zones of modern subalpine vegetation. Some seasonal moisture stress must still have existed, as is supported by the alkaliphilic, shallow-water diatom assemblages recorded during this interval (Bradbury, 1986). Towards the end of this interval, the decline of shrubs and herbs and the high proportions of Phyllocladus pollen among the other rain-forest types, especially the Pomaderris apetala type, suggest that precipitation had become less seasonal. In a similar fashion, the diatom changes indicating reduced moisture stress, and a transition to circumneutral-acidic and thence to acidic-dystrophic species, parallel the increase in rain-forest vegetation at both Lake Vera and Eagle Tarn. The correspondence of the diatom stratigraphy with the pollen record suggests a single control.

In the following interval (Zone 3 ) between 10,000 and 8,000 years B.P., Nothofagus cunninghamii and the Pomaderris apetala type reach their respective highest percentages, Athero- 
TABLE 2-Pollen assemblage characteristics of the four records (Figs. 4a and 4b) in relation to Nothofagus cunninghamii rain-forest groups (Table 1 and Fig. 3) and climatic parameters (Table 1). Climate values given in terms of mean annual precipitation and temperature, and mean summer (January through March) precipitation and temperature (in parentheses) (after Busby, 1984).

\begin{tabular}{|c|c|c|c|c|}
\hline YR. B.P. & ZONE & PRINCIPAL POLLEN DATA & VEGETATION ASSOCIATION & CLIMATE \\
\hline \multirow[t]{3}{*}{0} & \multirow[t]{3}{*}{6} & $\begin{array}{l}\text { Codominant: Nothofagus cunninghamii, } \\
\text { Phyllocladus } \\
\text { Abundant: Lagarostrobos (LV) } \\
\text { Low: Dicksonia, Eucalyptus }\end{array}$ & $\begin{array}{l}\text { montane/subalpine } \\
\text { rain forest }\end{array}$ & $\begin{array}{l}\text { L. Vera } \\
2,828 \mathrm{~mm}(468 \mathrm{~mm}) \\
8.7^{\circ} \mathrm{C}\left(12.7^{\circ} \mathrm{C}\right)\end{array}$ \\
\hline & & & $\begin{array}{l}\text { upper subalpine } \\
\text { rain forest }\end{array}$ & $\begin{array}{l}\text { Ooze L. } \\
1,856 \mathrm{~mm}(454 \mathrm{~mm}) \\
6.2^{\circ} \mathrm{C}\left(10.3^{\circ} \mathrm{C}\right)\end{array}$ \\
\hline & & $\begin{array}{l}\text { Codominant: } N \text {. cunninghamii, Eucalyptus } \\
\text { Low: Phyllocladus } \\
\text { Abundant: Dicksonia; some subalpine } \\
\text { conifers (ET) }\end{array}$ & $\begin{array}{l}\text { subalpine Eucalyptus } \\
\text { woodland-rain forest }\end{array}$ & $\begin{array}{l}\text { Eagle Tarn } \\
1,504 \mathrm{~mm}(262 \mathrm{~mm}) \\
5.7^{\circ} \mathrm{C}\left(10^{\circ} \mathrm{C}\right) \\
\text { Beatties Tarn } \\
1,500 \mathrm{~mm}(250 \mathrm{~mm}) \\
5.8^{\circ} \mathrm{C}\left(10^{\circ} \mathrm{C}\right)\end{array}$ \\
\hline 5,000 & 5 & $\begin{array}{l}\text { Decreased: } N \text {. cunninghamii } \\
\text { Increased: Phyllocladus } \\
\text { Abundant: Dicksonia, subalpine } \\
\text { sclerophyllous shrubs }\end{array}$ & $\begin{array}{l}\text { Tasmannia-Astelia } \\
\text { Alliance }\end{array}$ & $\begin{array}{l}2,093 \mathrm{~mm}(364 \mathrm{~mm}) \\
6.2^{\circ} \mathrm{C}\left(10.5^{\circ} \mathrm{C}\right)\end{array}$ \\
\hline 6,000 & 4 & $\begin{array}{l}\text { Dominant: N. cunninghamii } \\
\text { Increased: Phyllocladus, Dicksonia } \\
\text { High: Eucryphia-Anodopetalum type } \\
\text { Reduced: Pomaderris apetala type, } \\
\text { Eucalyptus } \\
\text { Discontinuous: Atherosperma }\end{array}$ & $\begin{array}{l}\text { Anodopetalum-Anopterus } \\
\text { Alliance }\end{array}$ & $\begin{array}{l}2,527 \mathrm{~mm}(439 \mathrm{~mm}) \\
9.3^{\circ} \mathrm{C}\left(13.3^{\circ} \mathrm{C}\right)\end{array}$ \\
\hline 8,000 & 3 & $\begin{array}{l}\text { Dominant: } N \text {. cunninghamii } \\
\text { Rel. Maximum: Pomaderris apet. type } \\
\text { High: Eucalyptus, Dicksonia (LV, ET) } \\
\text { Increasing: Eucryphia-Anodopetalum type } \\
\text { Consistent traces: Atherosperma } \\
\text { Low: Phyllocladus }\end{array}$ & $\begin{array}{l}\text { Dicksonia-Polystichum } \\
\text { Alliance }\end{array}$ & $\begin{array}{l}1,577 \mathrm{~mm}(253 \mathrm{~mm}) \\
10^{\circ} \mathrm{C}\left(14.4^{\circ} \mathrm{C}\right)\end{array}$ \\
\hline \multirow{2}{*}{10,000} & \multirow{2}{*}{2} & $\begin{array}{l}\text { Dominant: arboreal taxa (Phyllocladus }> \\
N . \text { cunninghamii }>\text { Pomaderris apetala } \\
\text { type and Eucalyptus } \\
\text { Low: non-arboreal taxa }\end{array}$ & $\begin{array}{l}\text { Dicksonia-Polystichum } \\
\text { Alliance }\end{array}$ & $\begin{array}{l}\text { no seasonal moisture } \\
\text { stress } \\
>1,200 \mathrm{~mm}\end{array}$ \\
\hline & & $\begin{array}{l}\text { Codominant: subalpine scleroph. shrubs, } \\
\text { Compositae, and arboreal taxa } \\
\text { (Phyllocladus }>N \text {. cunninghamii }> \\
\text { Pomaderris apetala type and Eucalyptus } \\
\text { Present: alpine taxa (Astelia, Plantago); }\end{array}$ & $\begin{array}{l}\sim \text { Tasmannia-Astelia } \\
\text { Alliance }\end{array}$ & $\begin{array}{l}\text { some seasonal } \\
\text { moisture stress } \\
>6^{\circ} \mathrm{C} \leqslant 9^{\circ} \mathrm{C} \\
<1,200 \mathrm{~mm}\end{array}$ \\
\hline 12,000 & 1 & $\begin{array}{l}\text { Dominant: Gramineae, Compositae, } \\
\text { Cyperaceae/Restionaceae } \\
\text { Low: arboreal taxa (Eucalyptus, } \\
\text { Phyllocladus, N. cunninghamii } \\
\text { Absent: alpine Taxa (Astelia and Planatago) }\end{array}$ & $\begin{array}{l}\text { steppe with marshes (instead } \\
\text { of lakes) }\end{array}$ & $\begin{array}{l}1,000 \mathrm{~mm} \\
6^{\circ} \mathrm{C} \\
\text { strong seasonal } \\
\text { moisture stress }\end{array}$ \\
\hline
\end{tabular}


sperma moschatum occurs consistently, and Phyllocladus decreases to relatively low levels. Even though Dicksonia is not a significant component during the early Holocene times, the taxa composition resembles the Dicksonia-Polystichum Alliance. Accordingly annual precipitation would have increased from less than $1,000 \mathrm{~mm}$ during Zone 1 to about $1,600 \mathrm{~mm}$ with mean annual temperatures of $10^{\circ} \mathrm{C}$, i.e., climatic conditions that were not yet characterized by maximum precipitation levels. Pollen records from Hunter Island (Hope, 1978) and Flinders Island (P. Ladd, pers. comm.), as well as the slow rise of lake levels during the early Holocene in Lake Keilambete in western Victoria (Bowler, 1981), support this interpretation. Pollen data from New Zealand also suggest a more drought-prone environment during the same period (McGlone and Topping, 1977).

The short-term dystrophic interval between 10,200 and 9,500 years B.P. recorded in the diatom analyses and interpreted as reflecting climates cooler and wetter than today (Bradbury, 1986), could relate to the brief decrease of the Pomaderris apetala type and increase in the EucryphiaAnodopetalum type at the onset of Zone 3 . The lower resolution of the pollen sequences, however, does not justify such detailed correlation.

The pollen assemblages between 8,000 and 6,000 years B.P. (Zone 4) are sufficiently distinct from the previous interval to suggest different environmental conditions. The most striking difference is the decrease of the Pomaderris apetala type, discontinuing occurrences of Atherosperma moschatum, and increase of the Eucryphia-Anodopetalum type and Phyllocladus. This taxa combination resembles the modern day Anodopetalum-Anopterus Alliance with over $2,500 \mathrm{~mm}$ mean annual precipitation and mean annual temperatures of less than $10^{\circ} \mathrm{C}$. The diatom data for this interval, even though not as detailed as the pollen data, support the interpretation of precipitation higher than today. Also during this time Lake Keilambete reached its highest levels (Bowler, 1981), and pollen data from New Zealand indicate equable and moist conditions between 8,000 and 6,000 years B.P. (McGlone and Topping, 1977).

Present in Zones 2 and 3 are both the Pomaderris apetala type and the Eucryphia-Anodopetalum type pollen that, according to the plant data, should discriminate between two different alliances and not co-occur. But because their occurrence is inversely related, and also correlates with specific shifts in Phyllocladus abundances, these taxa can be used to discriminate between these alliances in the fossil pollen zones. Zone 5 between 6,000 and 5,000 years B.P. suggests a markedly different environment. Subalpine shrubs and dwarf conifers return and Dicksonia increases. Increased inorganic sediment input into the basin and shallow-water, alkaliphilic diatoms at Lake Vera (Bradbury, 1986) all suggest a low-precipitation climate, similar to the early Holocene interval between 12,000 and 11,000 years B.P. Again the resemblance with the Tasmannia-Astelia Alliance is notable.

From 5,000 years B.P. onwards (Zone 6) essentially modern proportions of taxa are recorded. The most striking aspect of this change is the differentiation of the four sites into distinct environmental groups with different proportions of rain-forest taxa. Ooze Lake and Lake Vera records resemble each other quite closely, with high percentages of Nothofagus cunning- hamii, Phyllocladus, Lagarostrobos, but low values for Eucalyptus and Dicksonia, while Eagle and Beatties tarns (Mt. Field) have high values for Eucalyptus and Dicksonia and low values for the remainder of the rain-forest types. The difference in mean annual climate between the sites is $2,800 \mathrm{~mm}$ precipitation and $8.7^{\circ} \mathrm{C}$ temperature for Lake Vera vs. $1,800 \mathrm{~mm}$ and $6^{\circ} \mathrm{C}$ for Ooze Lake, and $1,500 \mathrm{~mm}$ and $6^{\circ} \mathrm{C}$ for Eagle and Beatties tarns (Mt. Field). Evidently, a threshold between regions of moisture deficit and moisture surplus had become established separating the two eastern sites on Mt. Field from the western and southwestern sites, whereas before 5,000 years B.P. this threshold either did not exist or was located east of Mt. Field. Possible explanations for this climatic shift are 1) steepening of the west-east precipitation gradient; or 2) increased climatic variability, including increased occurrence of abnormal moisture-stress conditions, caused, for example, by blocking patterns of the high-pressure cell over the Bight (eastern Victoria) (Nunez, pers. comm.). Overall, climatic conditions were characterized by an apparent decrease in effective moisture, as a result of a decrease in temperature coupled with a more or less pronounced decrease in precipitation. A drier and colder late Holocene is also reported from New Zealand (McGlone and Topping, 1977), and would also explain the lowering of lake levels in western Victoria (Bowler, 1981).

The modern geographic separation of the rain-forest associations (see Fig. 2) probably dates back to this time as well. The co-occurrence of all three alliances on Mt. Field, on the other hand, might be considered an early Holocene relict that continues to exist due to orographic reasons or niche diversity.

\section{CONCLUSIONS}

Prior to the plant-sociological classification of the Nothofagus cunninghamii rain-forest vegetation in Australia (Busby, 1984), little quantitative data was available on the floristic composition and environmental factors that correlate with the distribution of plant taxa in the rain forest. One study whose results could have been applied to the present study of fossil rain-forest assemblages was based on a gradient analysis of the rain-forest vegetation on Mt. Field (Ogden and Powell, 1979). These authors demonstrated that along the elevational transect studied, specific plant groups occur in a clear zonation with ecological significance. Such data from mountain transects, however, may not be directly applicable to past environmental changes that generate horizontal as well as altitudinal shifts of vegetation zones. Generally, the orographic characteristics of mountains seem to enhance vegetational zonation that is difficult to assess in a regional cortext and that may not yield adequate estimates for past environmental changes. Thus, in the case of the Tasmanian pollen records, Busby's (1984) approach seemed more holistic because it considered the whole distributional range of the rain-forest vegetation. The climatic correlations with the specific floristic groups then provided quantitative precipitation and temperature parameters, annual as well as seasonal, from throughout Tasmania, that could be related to specific pollen assemblages on the basis of comparison of species composition. This method is not only more objective than other previously used methods, but also permits us to interpret which of the two parameters, precipitation or temperature, might have been primarily responsible for a given 
environmental shift. On the other hand, both parameters cannot be analyzed separately, because they are interrelated, and "effective moisture" may have greater ecological significance than either precipitation or temperature values alone. This point is illustrated by comparison of the environmental situations of Lake Vera and Ooze Lake. While Lake Vera receives $2,800 \mathrm{~mm}$ mean annual precipitation under $8.7^{\circ} \mathrm{C}$ mean annual temperatures, Ooze Lake receives $1,800 \mathrm{~mm}$ under $6^{\circ} \mathrm{C}$. Effective moisture, however, may be similar for both sites, and thus the environment is similar.

The described climatic difference between the mid-Holocene interval 8,000 to 6,000 years B.P. and the late Holocene from 5,000 years B.P. to present, is not simply a temperature decrease from an original value of $9^{\circ}$, to $4^{\circ}$ or $5^{\circ} \mathrm{C}$, depending on the site, but instead is an increase in precipitation and temperature for Lake Vera and Ooze Lake vs. a much smaller precipitation increase coupled with a temperature decrease for the Mt. Field sites. If the temperature shift were considered alone, it certainly would result in a dramatic shift of the upper timberline (unsupported by pollen data). The apparent $4^{\circ} \mathrm{C}$ temperature decrease has to be assessed against the simultaneous decrease in precipitation from 2,500 $\mathrm{mm}$ to $1,500 \mathrm{~mm}$ annually and the resultant decrease in effective moisture. Even though the temperature and precipitation values cannot be discounted $a$ priori, because they reflect the modern magnitude of climatic range for the rain forest, they have to be read against the background of an integrated climatic understanding.

The ability to differentiate between climatic parameters and their changes through time, even in seasonal terms, however, is a most exciting advance in paleoclimatic research, because it permits us to relate regional climatic patterns to larger-scale atmospheric circulation patterns, ultimately on a global scale.

\section{ACKNOWLEDGMENTS}

Partial support for this study came from the National Science Foundation, Office of Climate Dynamics (ATM-8212836) awarded to V. Markgraf. The authors V.M. and J.P.B. gratefully acknowledge the Australian National University through the Research School of Pacific Studies, Department of Biogeography and Geomorphology, for arranging and supporting this study while visiting Australia. We are particularly thankful to the many collegues in Australia who shared their ideas on the project and helped to shape the study through valuable discussions. Especially appreciated were the critical comments by M. Macphail, E. Colhoun, and M. Nunez during the first stages of the manuscript. For further discussion we thank J. Bowler, D. Green, G. Hope, R. Jennings, J. Kirkpatrick, and G. Singh. We are indebted to M. McGlone, J. Ogden, D. Pocknell, and T. Webb III for thoughtful editing and criticism on the final manuscript. Participation of J.P.B. in this study is part of the U.S. Geological Survey Climate Change Program.

\section{REFERENCES}

Bartlein, P.J., Prentice, I.C., and Webb, III, T., 1986, Climatic response surfaces from pollen data for some eastern North American taxa: Journal of Biogeography, v. 13, p. 35-57.
BowLER, J.M., 1981, Australian salt lakes: a palaeohydrologic approach: Hydrobiologia, v. 82, p. 431-444.

BOWLER, J.M., 1982, Aridity in the late Tertiary and Quaternary of Australia, in BARKER, W.R., and GreEnsLadE, P.J.M., eds., Evolution of the Flora and Fauna of Arid Australia: Adelaide, Peacock Publications, p. $35-45$.

BradbuRY, J.P., 1986, Late Pleistocene and Holocene paleolimnology of two mountain lakes in western Tasmania: PALAIOS, v. 1, p. 381-388.

BRYSON, R.E., 1985, On climatic analogs in paleoclimatic reconstruction: Quaternary Research, v. 23, p. 275-286.

BusBY, J.R., 1984, Nothofagus cunninghamii (Southern Beech) Vegetation in Australia: Australian Flora and Fauna Series No. 1, Canberra, Australian Government Publication Service, $69 \mathrm{p}$.

BusbY, J.R., A biological analysis of Nothofagus cunningamii (Hook.) Oerst, in southeastern Australia: Australian Journal of Ecology (in press).

Colhoun, E.A., 1983, The climate of Tasmania 15-10 KA, $7 \pm 2$ KA B.P., in Chappell, J., and Grindrod, A., eds., Proceedings of the First CLIMANZ Conference, Feb. 1981: Canberra, Department of Biogeography and Geomorphology, RSPacS, Australian National University, pp. 72-74, 93-94.

Colhoun, E.A., Geer, G., van DE, and Mook, W.G., 1982, Stratigraphy, pollen analysis, and paleoclimatic interpretation of Pulbeena Swamp, northwestern Tasmania: Quaternary Research, v. 18, p. 108-126.

FAeGri, K., and Iversen, J., 1975, Textbook of Pollen Analysis: Copenhagen, Munksgaard, $195 \mathrm{p}$.

HoPE, G.S., 1978, The Late Pleistocene and Holocene vegetational history of Hunter Island, north-western Tasmania: Australian Journal of Botany, v. 26 , p. $493-514$.

Hurchinson, M.F., 1983, A new objective method for spatial interpolation of meteorological variables from irregular networks applied to the estimation of monthly mean solar radiation, temperature, precipitation and windrun: United Nations University Workshop, Need for Climatic and Hydrologic Data in Agriculture of S.E. Asia, Canberra, Dec. 1983.

HUTCHINSON, M.F., 1984, A summary of some surface fitting and contouring programs for noisy data: Consulting Report No. ACT 84/6, Canberra, Commonwealth Scientific and Industrial Research Organization (Australia). Division of Mathematics and Statistics. Division of Water and Land Resources, $24 \mathrm{p}$.

JANSSEN, C.R., 1973, Local and regional pollen deposition, in BIRKS, H.J.B., and WEST, R.G., eds., Quaternary Plant Ecology: Oxford, Blackwell, pp. 31-42.

KirKPATRICK, J.B., and DiCKINSON, K.J.M., 1984, Vegetation of Tasmania: Forestry Commision of Tasmania, Map 1:500,000.

Kutzвach, J.E., and GuetTer, P.J., 1984, Sensitivity of Late-glacial and Holocene climates to the combined effects of orbital parameter changes and lower boundary condition changes: 'snapshot' simulations with a general circulation model for 18-, 9-, and 6KA B.P.: Annals of Glaciology, v. 5 , p. $85-87$.

MacPhall, M.K., 1975, Late Pleistocene environments in Tasmania: Search, v, 6 , p. $295-300$.

MacPhall, M.K., 1976, The history of the Vegetation and Climate in Southern Tasmania Since the Late Pleistocene (ca. 13,000-0 B.P.) [Ph.D. Thesis]:University of Tasmania, p. 1-330.

MaCPHAIL, M.K., 1979, Vegetation and climates in southern Tasmania since the last glaciation: Quaternary Research, v. 11, p. 306-341.

MACPHAIL, M.K., 1983, Structural changes in the highland vegetation of southeastern Australia during the early to middle Holocene, in CHAPPELL, J., and Grindrod, A., eds., Proceedings First CLIMANZ Conference, Feb. 1981: Canberra, Department of Biogeography and Geomorphology, RSPacS, Australian National University, p. 103-105.

MACPhAIL, M.K., and ColHOUN, E.A., 1985, Late last glacial vegetation, climates, and fire activity in Southwest Tasmania: Search, v. 16, p. $43-45$.

MacPhaIL, M.K., and JACKSON, W.D., 1978, The Late Pleistocene and Holocene history of the Midlands of Tasmania, Australia: pollen evidence from Lake Tiberias: Proceedings of the Royal Society of Victoria, v. 90, p. $287-300$. 
MAHER, L.J., 1963, Pollen analyses of surface materials from the southern San Juan Mountains, Colorado: Geological Society of America Bulletin, v. 74 , p. $1485-1504$

MARKGRAF, V., 1980, Pollen dispersal in a mountain area: Grana, v. 19, p. $127-146$.

MarkGRAF, V., 1984, Paleoclimatic correlation between southern South America and Australia/Tasmania: 6th International Palynological Conference, Calgary, Abstracts, p. 100.

McGlone, M.S., and BATHGATE, J.L., 1983, Vegetation and climate history of the Longwood Range, South Island, New Zealand, 12,000 B.P. to present: New Zealand Journal of Botany, v. 21, p. 293-315.

MCGLONE, M.S., and ToPPING, W.W., 1977, Aranuian (post-glacial) pollen diagrams from the Tongariro region, North Island, New Zealand: New Zealand Journal of Botany, v. 15, p. 749-760.

NoBLE, M.G., The detection of non-equilibrium distributional patterns in Tasmania using stochastic models, in BArLow, B.A., ed., Flora and Fauna of Alpine Australasia: Ages and Origins: Melbourne, CSIRO (in press).

NUNE2, M., 1978, The radiation index of dryness in Tasmania: Australian Geographical Studies, v. 16, p. 126-135.

OGdEN, J., and Powell, J.A., 1979, A quantitative description of the forest vegetation on an altitudinal gradient in the Mount Field National Park,
Tasmania, and a discussion of its history and dynamics: Australian Journal of Ecology, v. 4, p. 293-325.

OverPeCK, J.T., WeBB III, T., and Prentice, I.C., 1985, Quantitative interpretation of fossil pollen spectra: dissimilarity coefficients and the method of modern analog: Quaternary Research, v. 23, p. 87-108.

PRENTICE, I.C., 1985, Pollen representation, source area, and basin size: toward a unified theory of pollen analysis: Quaternary Research, v. 23, p. $76-86$

WASHBA, G., and WendelBerger, J., 1980, Some new mathematical methods for variational objective analysis using splines and crossvalidation: Monthly Weather Review, v. 108, p. 1122-1143.

WEBB, T., 1985, Holocene palynology and climate, in HechT, A.D., ed., Paleoclimate Analysis and Modeling: New York, J. Wiley and Sons, p. 163-196.

WeBB III, T., and Bryson, R.A., 1972, Late- and post-glacial climatic change in the Northern Midwest U.S.A.: quantitative estimates derived from fossil pollen spectra by multivariate statistical analysis: Quaternary Research, v. 2, p. 70-115.

WebB III, T., Howe, S.E., Bradshaw, R.H.W., and Heide, K., 1981, Estimating plant abundances from pollen percentages: the use of regression analysis: Review of Paleobotany and Palynology, v. 34, p. $269-300$.

APPENDIX

Higher Plant Species Mentioned in Text

Species Name and Authority

Family

Growth Form

Anodopetalum biglandulosum (Hook.) Hook. f.

Anopterus glandulosus Labill.

Astelia alpina $\mathrm{R}$. Br.

Atherosperma moschatum Labill.

Athrotaxis spp.

Bellendena montana $\mathrm{R}$. Br.

Blechnum wattsii Tindale

Casuarina sp.

Dicksonia antarctica Labill.

Diselma sp.

Eucalyptus coccifera Hook. f.

Eucalyptus delegatensis R.T. Baker

Eucalyptus obliqua L'Herit.

Eucalyptus simmondsii Maiden

Eucalyptus subcrenulata Maiden \& Blakely

Eucryphia lucida (Labill.) Baill.

Grammitis billardieri Willd.

Lagarostrobos franklinii (Hook. f.) Quinn

Microcachrys sp.

Microstrobos sp.

Milligania sp.

Nothofagus cunninghamii (Hook.) Oerst.

Orites spp.

Phyllocladus aspleniifolius (Labill.) Hook. f.

Plantago spp.

Podocarpus sp.

Polystichum proliferum (R. Br.) C. Presl

Pomaderris apetala Labill.

Richea spp.

Tasmannia lanceolata (Poir.) A. C. Smith

CUNONIACEAE
GROSSULARIACEAE
LILIACEAE
MONIMIACEAE
TAXODIACEAE
PROTEACEAE
BLECHNACEAE
CASUARINACEAE
DICKSONIACEAE
CUPRESSACEAE
MYRTACEAE
MYRTACEAE
MYRTACEAE
MYRTACEAE
MYRTACEAE
EUCRYPHIACEAE
GRAMMITIDACEAE
PODOCARPACEAE
PODOCARPACEAE
PODOCARPACEAE
LILIACEAE
FAGACEAE
PROTEACEAE
PODOCARPACEAE
PLANTAGINACEAE
PODOCARPACEAE
ASPIDIACEAE
RHAMNACEAE
EPACRIDACEAE
WINTERACEAE

shrub

shrub

herb

shrub/tree

tree

dwarf shrub

fern

tree

tree fern

shrub

shrub/tree

tree

tree

tree

small tree

tree

epiphytic fern

tree

dwarf shrub

shrub

herb

shrub/tree

shrub

tree

herb

shrub

fern

small tree

shrub

shrub
(E)

(E)

(E)

(E)

(E)-endemic, i.e. now restricted to Tasmania. 